\title{
Percutaneous dilatation of aortic coarctation with balloon angioplasty and/or stent implantation - own experience
}

Przeznaczyniowe poszerzanie koarktacji aorty za pomocą balonowej angioplastyki i/lub implantacji stentu - doświadczenia własne

\section{Małgorzata Szkutnik, Jacek Białkowski, Roland Fiszer}

Department of Congenital Heart Disease and Pediatric Cardiology, Silesian Medical University, Silesian Center for Heart Diseases, Zabrze, Poland

\section{Abstract}

Post Kardiol Interw 2010; 6, 1 (19): 1-5

Background: Results of percutaneous dilatation of native aorta coarctations (COA) and recoarctations after previous surgical procedures $(\mathrm{ReCOA})$ are not frequently published.

Aim: To assess results of balloon angioplasty (BAP) and/or stent implantation (SI) in the treatment of patients (pts) with aortic coarctation and recoarctation.

Material and methods: BAP and/or SI were performed in 203 pts: 110 with native CoA and 93 with ReCoA, aged 0.3-57 (median 15) years. In cases of discrete native CoA BAP was performed with usually low pressure balloons whereas in ReCoA high pressure balloons were used. Depending on the availability the following stents were applied - Palmaz, Cheatham Platinum (CP), covered CP and nitinol self-expandable.

Results: BAP was performed during 184 procedures and SI was done in 64 pts. In native aorta coarctation BAP was successful in $82.9 \%$ of pts and in all 45 pts with SI (despite 4 stent migrations) a good result was obtained. In ReCoA BAP was effectively performed in $79.2 \%$ of pts, whereas SI - in $72.2 \%$ (13/18) pts (stiff postsurgical lesions). After BAP/SI aortic aneurysm/dissection occurred in 1 patient with native CoA and in 3 pts with ReCoA - 3 of them were treated with covered stent and one was treated surgically. In a 53 years old woman with native COA and an aortic aneurysm a mild stroke occurred during an implantation of a covered stent. One 6.5 years old girl suffered from femoral thrombosis after SI and required surgical treatment.

Conclusions: In the majority of patients with aortic coarctation BAP or SI are the effective methods of treatment. The treatment strategy should be however always selected individually.

Key words: coarctation of aorta, angioplasty, stent implantation

\section{Streszczenie}

Wstęp: Wyniki dotyczące przeznaczyniowego poszerzania natywnej koarktacji aorty (CoA) oraz rekoarktacji po jej uprzednim leczeniu chirurgicznym (ReCoA) nie są zbyt często publikowane.

Cel: Określenie skuteczności angioplastyki balonowej (BAP) i/lub implantacji stentów (SI) u pacjentów z CoA i ReCoA.

Materiał i metody: Angioplastykę balonową i/lub SI wykonano u 203 pacjentów w wieku 0,3-57 lat (mediana 15 lat) - 110 z natywną CoA i 93 z ReCoA. Podczas BAP w przypadkach zlokalizowanej CoA zwykle stosowano balony niskociśnieniowe, a w przypadkach ReCoA wysokociśnieniowe. W zależności od dostępności używano następujących typów stentów: Palmaz, Cheatham Platinum (CP), covered CP i nitinolowe samorozprężalne.

Wyniki: Angioplstykę balonową przeprowadzono łącznie podczas 187 zabiegów, SI podczas 64. W przypadku CoA BAP była efektywna u 82,9\% pacjentów, natomiast SI u wszystkich chorych (pomimo przemieszczenia stentu u 4 osób). W przypadku ReCoA BAP była skuteczna u 79,2\%, a SI u 72,2\% (13/18) pacjentów (obecność niepodatnych zmian pochirurgicznych). Obecność tętniaka lub rozwarstwienia aorty po BAP stwierdzono u jednego chorego z CoA oraz u 3 z ReCoA. Powikłanie to zostało zaopatrzone poprzez zastosowanie stentu covered u 3 pacjentów a u jednego - kardiochirurgicznie. Udar ośrodkowego układu nerwowego wystąpił u 53-letniej kobiety z CoA i samoistnym tętniakiem aorty, u której planowo wszczepiano stent covered. U 6,5-letniej dziewczynki po SI wystąpiła zakrzepica tętnicy udowej, która wymagała chirurgicznej trombektomii.

Wnioski: Angioplastyka balonowa bądź implantacja stentów stanowi efektywną metodę leczenia CoA lub ReCoA u większości pacjentów. Strategia leczenia w każdym przypadku musi być dobrana indywidualnie.

Słowa kluczowe: koarktacja aorty, angioplastyka, stenty

Adres do korespondencji/Corresponding author:

Prof. Jacek Białkowski MD, PhD, Katedra i Kliniczny Oddział Wrodzonych Wad Serca i Kardiologii Dziecięcej, Śląski Uniwersytet Medyczny,

Śląskie Centrum Chorób Serca, ul. Szpitalna 2, 41-800 Zabrze, tel.: +48 3227134 01, e-mail: jabi_med@poczta.onet.pl

Praca wpłynęła 02.12.2009, przyjęta do druku 25.01.2010. 


\section{Introduction}

Coarctation of the aortic isthmus constitutes about $6 \%$ of congenital heart defects [1]. In 50\% of cases coarctation is associated with bicuspid aortic valve. Coarctation of aorta is more common in females with Turner syndrome. In 1980s balloon angiplasty (BAP) was introduced in the treatment of aortic coarctation. At the beginning the use of BAP in native aortic coarctation ( $\mathrm{COA}$ ) was controversial due to the fear of such complications as an aortic aneurysm formation [2]. Since 1990s BAP has become an alternative for surgery in untreated native CoA and a first choice treatment in postoperative recoarctation of the aorta (ReCoA) [3-5]. Stent implantation is usually efficient in the treatment of varied anatomic variants of the defect such as tubular coarctations coexisting with hypotrophy of the aortic isthmus or recurrent coarctations after balloon angioplasty [6]. In many centers stent implantation (SI) is an established first choice treatment in coarctation of the native aorta. Patients in whom physical developement warrants subsequent stent redilation to the diameter of the adult aorta should be referred for SI.

Although transluminal dilatation of COA is currently a widely used treatment method the results of such therapy are not frequently published.

The aim of this report is to establish on the basis of our own experience the efficacy of the transluminal dilatation of COA by means of BAP and/or SI in patients with native CoA and ReCoA.

\section{Material and methods}

Between 1994 and 2009 transluminal dilatation of COA was performed in 203 patients of the age of 0.3-57 years (median 15 years). Children ( $<18$-year-old) were the majority in the study group (157 children). In all patients the symptoms of systemic upper-body hypertension with a pressure gradient at the aortic isthmus of above $30 \mathrm{~mm} \mathrm{Hg}$ by Doppler echocardiography were recognised. Depending on the age of patients, morphology of COA and previous procedures the BAP and/or SI procedures were performed. The procedure was claimed successful when the pressure gradient in Doppler echocardiography was less than $20 \mathrm{~mm} \mathrm{Hg}$ in the long term follow up. In cases of localised native CoA low pressure balloons were usually used (TyShak by Numed, fig. 1. A, B , C) whereas in ReCoA high pressure balloons were applied (Maxi by Cordis). Depending on the availability the following stent types were implanted: Palmaz, Cheatham Platinum (CP), covered $\mathrm{CP}$ and nitinol self-expandable systems. Palmaz stents are made of steel with sharp ends, CP are round-edged and composed of gold and platinium. Covered CP stents are covered with expandable sleeve. Nitinol systems are made of tytanium and nickel.

\section{Results}

Altogether 247 procedures were performed with no fatal complication. BAP was performed as a first choice treatment in 76 patients with native COA and in 78 patients with ReCoA (tab. 1). Stents were implanted in 63 patients (45 with native CoA and 18 with ReCoA) (tab. 2). In one patient patent ductus arteriousus was closed with intravascular coil simultaneously with the balloon angioplasty procedure, in subsequent 3 patients balloon valvuloplasty of narrowed aortic valve was performed. In 11 patients SI was performed following failed BAP. In other 4 patients with severe COA SI procedure was performed after scheduled BAP (predilatation). Subsequent redilatation of the stent was performed in 17 patients. In native CoA BAP was unsuccessful in $17.1 \%$ of patients (13 patients), whereas all SI precuders were efficient despite stent migration in 4 patients. Stent migration occured proximally to the stent placement in 2 patients and distally in another two. In all cases however efficient dilatation of coarctation
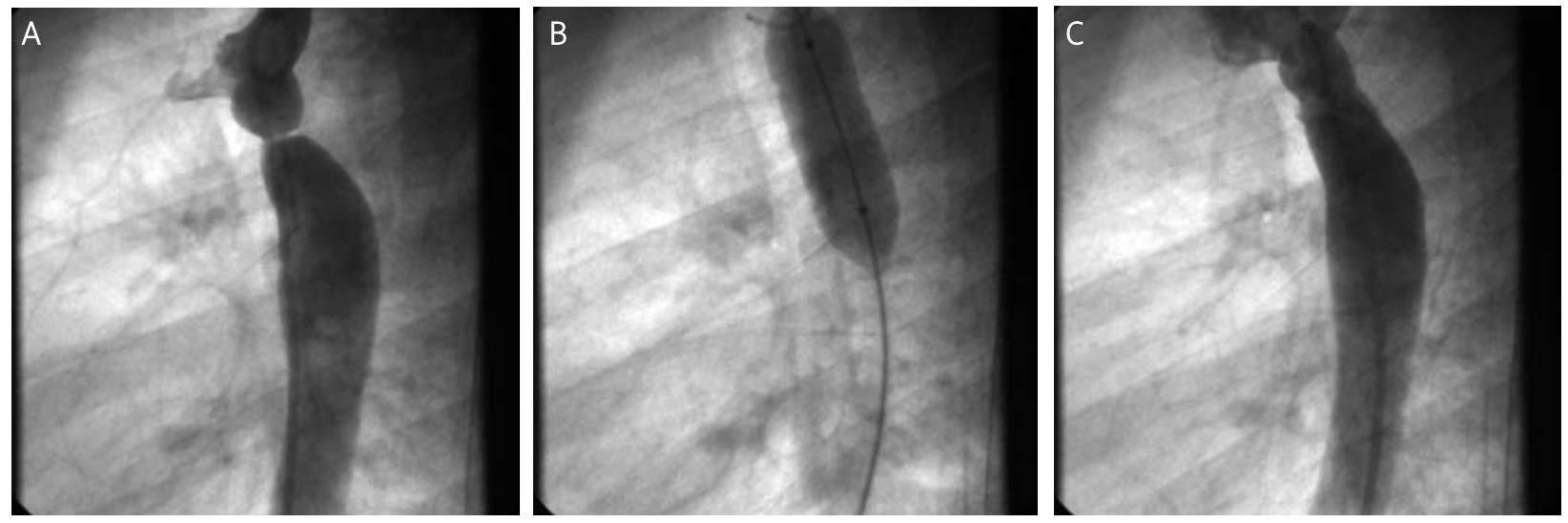

Fig. 1. A - localised membranous type of native aortic coarctation in a 5-year-old boy; B - balloon angioplasty (BAP); C - good effect of the BAP procedure

Ryc. 1. A - miejscowa, błoniasta postać natywnej koarktacji aorty u 5-letniego chłopca; $B$ - angioplastyka balonowa (BAP); $C$-dobry efekt zabiegu BAP 
Table 1. Clinical data and results of balloon angioplasty in the treatment of coarctation of the aorta Tabela 1. Dane kliniczne oraz wyniki zabiegu angioplastyki balonowej w leczeniu koarktacji aorty

\begin{tabular}{lcc} 
Clinical data & Angioplasty of CoA & Angioplasty of ReCoA \\
\hline Number of patients & 76 & 78 \\
\hline Age [years] min-max (median) & $0.3-46(10)$ & $0.2-55(1.3)$ \\
\hline Weight [kg] min-max (median) & $5.7-85(29)$ & $2.6-98.5(10)$ \\
\hline Pressure gradient before the procedure [mm Hg] min-max (median) & $18-86(38)$ & $18-90(34)$ \\
\hline Pressure gradient after the procedure [mm Hg] min-max (median) & $0-39(11)$ & $0-44(12)$ \\
\hline Coarctation before the procedure [mm] min-max (median) & $1.3-12(3.6)$ & $1-13(3.5)$ \\
\hline Coarctation after the procedure [mm] min-max (median) & $3.2-15(7)$ & $2.7-16(6)$ \\
\hline Post-procedural to pre-procedural aorta diameter ratio min-max (median) & $1-4.5(2)$ & $1-3.2(1.8)$ \\
\hline Balloon to coarctation diameter ratio min-max (median) & $1.5-6(2.7)$ & $1.4-5.5(2.4)$ \\
\hline Reinterventions (number of patients) & 22 & 9 \\
\hline Follow up [years] min-max (median) & $0.2-11.5(4.6)$ & $0.1-15.6(5.5)$ \\
\hline Percentage of failed angioplasty [\%] & 17.1 & 20.8
\end{tabular}

Table 2. Clinical data and the results of stent implantation in the treatment of coarctation of the aorta Tabela 2. Dane kliniczne oraz wyniki zabiegu implantacji stentów w leczeniu koarktacji aorty

\begin{tabular}{lcc}
\hline Clinical data & Stents in CoA & Stents in ReCoA \\
\hline Number of patients & 45 & 18 \\
\hline Age [years] min-max (median) & $6.5-57(22)$ & $10-54(23)$ \\
\hline Weight [kg] min-max (median) & $25-97(57)$ & $27-122(67)$ \\
\hline Pressure gradient before the procedure [mm Hg] min-max (median) & $18-75(48)$ & $26-111(40.5)$ \\
\hline Pressure gradient after the procedure [mm Hg] min-max (median) & $0-25(8)$ & $0-37(14.5)$ \\
\hline Coarctation before the procedure [mm] min-max (median) & $2-10(5.0)$ & $3.5-10(6.3)$ \\
\hline Coarctation after the procedure [mm] min-max (median) & $5.5-19(14)$ & $7.5-17(12.5)$ \\
\hline Post-procedural to pre-procedural aorta diameter ratio min-max (median) & $1.2-8(2.4)$ & $1.3-3.8(1.7)$ \\
\hline Balloon to coarctation diameter ratio min-max (median) & $1.4-8(3.2)$ & $1.6-4.6(2.2)$ \\
\hline Reinterventions (number of patients) & 8 (successful balloon & 7 (redilatation in 6, \\
& redilatation) & stent implantation in 1) \\
\hline Follow up [years] min-max (median) & $0.1-7.3(3.2)$ & $0.9-10.5(4.0)$ \\
\hline Percentage of failed procedures & 0 & failed redilatation in 6 pts
\end{tabular}

by the migrating stent was observed (Palmaz stents were used in 2 cases - 1 SA, 1 CP). In cases of ReCoA BAP was inefficient in 20,8\% of patients (16 patients). Among 18 patients with SI for ReCoA 5 patients had suboptimal stent expansion despite application of a high pressure balloon which was cased by aortic wall changes related to previous surgeries. Three patients with aortic valve incompetence associated with a dilatation of ascending aorta underwent Bentall's procedure: one patient had operation 1 month before $\mathrm{SI}$ and 2 other patients were operated on 2 and 5 months after SI procedure. There were 3 cases of aortic aneurysm diagnosed after BAP procedure: in one patient with native CoA and in 2 patients with ReCoA. Two of those patients were treated subsequently with covered stent implantation and one patient underwent cardiosurgical procedure. A covered stent was used in a 13-year-old girl after two failed balloon angioplasties of COA to treat an saccular aneurysm at the level of coarctation (fig. 2. A, B). In one case of a 40-year-old male with ReCoA BAP was performed as a predilatation and led to acute dissection of the aorta with a sudden drop in blood pressure. A covered stent was immidiately used to close the initial tear of the dissection with successful dilatation of the coarctation. Among other complications a stroke occured in a 53-yearold woman with native CoA and an aortic aneurysm after a scheduled procedure of covered stent implantation. In a 6.5-year-old girl undergoing SI procedure a femoral artery thrombosis occured and required surgical thrombectomy. 

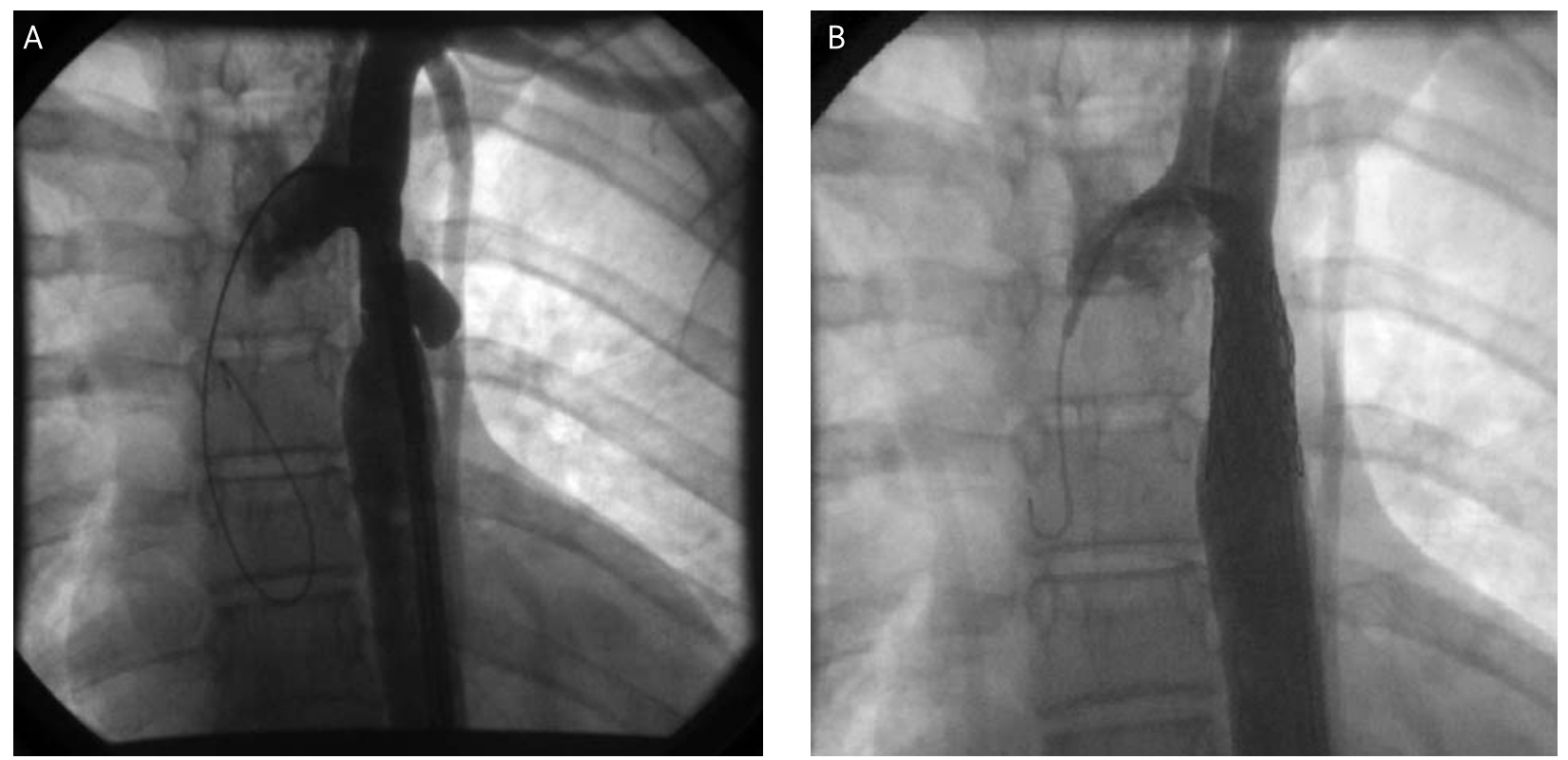

Fig. 2. A - two previous balloon angioplasties in a 13-year-old girl. Tubular type of CoA and saccular aneursym can be seen. B - $34 \mathrm{~mm}$ covered CP stent implatnation. Separation of the aneurysm from the aortic lumen, dilatation of the hypoplastic aortic isthmus. Stent redilatation planned in future

Ryc. 2. A - stan po 2-krotnej balonowej angioplastyce u 13-letniej dziewczynki. Widoczna tubularna postać CoA oraz workowaty tętniak. B - implantacja stentu covered CP o długości $34 \mathrm{~mm}$. Oddzielenie tętniaka od światła aorty oraz poszerzenie hipoplastycznego odcinka cieśni. W przyszłości planowana jest redylatacja stentu

\section{Discussion}

Transluminal angioplasty of the coarcation of the aortic isthmus in both native aorta and aortic recoarctation after surgical treatment of the aortic arch has become a first choice treatment over last several years. This does not refer to the youngest patient group up to 6 months of age where cardiosurgery is still the preferable treatment. However, it should be remembered that also in some cases after balloon angioplasty a recurrent coarctation can occur especially in cases of elastic recoil that is a rebound of the fibroelastic tissue in the area of coarctation after balloon dilatation. Balloon angiplasty cannot be performed in aortic hypoplasia when the coarctation is spread along aorta. In those cases stent implantation can be performed.

Stents are made of wire metal mesh. They are fixed on a balloon catheter and subsequently expanded in the region of coarctation to obtain persistent dilatation of the aorta (also in case of longer hypoplastic segments). The limitation of the technique is the need to use large vascular sheaths to introduce stents into the aorta lumen. Therefore they can be used only in patients with body weight of above $25-30 \mathrm{~kg}$ thus after $7^{\text {th }}$ year of age. On the other hand a future height of the patient and the need for stent redilatation to the diameter of the adult aorta should be taken into account. This treatment method is especially favorable in adult patients with arteriosclerosis and extensive collateral circulation proximally and distally to coarctation. In this patient group the risk of surgical treatment is exceptionally high (difficult anatomy, presence of collaterals, aortic wall calcifications, risk of paraplegia secondary to spinal cord ischaemia) [7]. The potential risk of stent implantation (similarly to balloon angioplasty of the coarctation) is the aortic wall rupture with aneurysm formation or aortic wall dissection. The procedure envolves rupture of the intimal layer and partial rupture of the muscular layer of the aortic wall. The incidence of the aneurysm or dissection is assessed as between 0 to $17 \%$ [5, 7-9] but most of the aneurysms are of a small size, do not extend and require only monitoring (follow up imaging, preferably MRI). The incidence between 0 and $9 \%$ of large aneurysms (requiring intervention treatment) is reported in literature. In these cases an implantation of a covered stent, which is a stent covered with expandable sleeve (pTFE - polytetrafluoroethylene), is the treatment of choice [10]. It is worth mentioning that according to our own experience a formation of a large aortic aneurysm responsible for the aorto-bronchial fistula can also take place after surgical treatment of COA [11]. Our own experience alo indicates that there is a possibility of nonsurgical reconstruction of functionally interrupted aortic arch at the point of CoA by means of a stent implantation [12]. There are hopes for future use of stents that could be implanted in the youngest patient group such as 
bioabsorbable stents or stents consisting of two stent halves made of metal and connected by reabsorbable sutures [13]. There is no definite answer which of the interventional methods currently used: balloon angioplasty or stent implantation is better in the treatment of the aortic coarctation [6, 14-19].

It should be emphysised that transcatheter procedures of CoA dilatation should be performed only by the most experienced teams of interventional cardiologists. Additionally it is necessary to provide cathlabs with covered stents (to be used immidiately in case of rupture or dissection of the aortic wall during procedure) and cardiosurgical backup. Covered stents were efficient in the treatment of complications in 3 of our patients including two aortic aneurysms post-BAP. An application of a covered stent safed life of a patient with aortic dissection post-BAP.

\section{Conclusions}

Balloon angioplasty or stent implantation are efficient methods of treating CoA in native aorta or recoarctation after cardiosurgical treatment. Treatment strategy should be chosen individually in every case.

\section{References}

1. Hoffman J, Christainson R. Congenital hearet diseases in a cohort of 19502 births with long term follow-up. Am J Cardiol 1978; 42: 641-647.

2. Tynan M, Finley JP, Fontes V, et al. Balloon angioplasty for the treatment of native coarctation: results of valvuloplasty and angioplasty of congenital anomalies registry. Am J Cardiol 1990; 65: 790-792.

3. Hellebrand WE, Allen HD, Golinko RJ. Balloon angioplasty of aortic recoarctation: results of valvuloplasty and angioplasrty of congenital anomalies registry. Am J Cardiol 1990; 65: 793-797.

4. Hassan W, Malik S, Akhras N, et al. Long-term results (up to 18 years) of balloon angioplasty on systemic hypertension in adolescent and adult patients with coarctation of the aorta. Clin Cardiol 2007; 30: 75-80.

5. Shih MP, Tholpady A, Kramer CM, et al. Surgical and endovascular repair of aortic coarctation: normal findings and apperance of complications on CT angiography and MR angiography. AJR 2006; 187: W302-312.
6. Suarez de Lezo J, Pan M, Romero M, et al. Percutaneous interventions on severe coarctation of the aorta: a 21-year experience. Pediatr Cardiol 2005; 26: 176-189.

7. Golden AB, Hellenbrand WE. Coarctation of the aorta: stenting in children and adults. Cathet Cardiovasc Interv 2007; 69: 289-299.

8. Forbes TJ, Garekar S, Amin Z, et al. Procedural results and acute complications in stenting native and recurrent coarctation of the aorta in patients over 4 years of age: a multi-institutional study. Cathet Cardiovasc Interv 2007; 70: 276-285.

9. Schaeffler R, Kolax T, Hesse C, Peuster M. Implanation of stents for treatment of recurrent and antive coarctation in children weighing less than 20 kilograms. Cardiol Young 2007; 17: 617-622.

10. Tzifa A, Ewert P, Brzezińska-Rajszys G, et al. Covered Cheatamplatinum stents for aortic coarctation: early and intermediateterm results. J Am Coll Cardiol 2006; 47: 1457-1463.

11. Kusa J, Białkowski J, Szkutnik M, et al. Przetoka aortalno-oskrzelowa po chirurgicznym zabiegu poszerzenia koarktacji aorty leczona za pomocą stentgraftu. Standardy Medyczne 2005; 7: 111-114.

12. Kusa J, Szkutnik M, Białkowski J. Percutaneous reconstruction of the continuity of a functionally interrupted aortic arch using a stent. Cardiol J 2008; 15: 80-84.

13. Ewert P, Peters B, Nagdyman N, et al. Early and mid-term results with the growth stent- a possible concept for transcatheter treatment of aortic coarctation from infancy to adulthood by stent implantation? Cathet Cardiovasc Interv 2008; 71: 120-126.

14. Zabal C, Attie F, Rosas M, et al. The adult patient with native coarctation of the aorta: balloon angioplasty or primary stenting? Haert 2003; 89: 77-83.

15. Ovaert C, McCrindle BW, Nykanen D, et al. Balloon angioplasty of native coarctation: clinical outcomes and predictors of success. J Am Coll Cardiol 2000; 35: 988-996.

16. Fawzy ME, Sivanandam V, Galal O, et al. One- to ten-year followup results of balloon angioplasty of native coarctation of the aorta in adolescents and adults. J Am Col Cardiol 1997; 30: 1542-1546.

17. Pedra CAC, Fontes VF, Esteves CA, et al. Stenting vs. balloon angioplasty for discrete unoperated coarctation of the aorta in adolescents and adults. Cath Cardiovasc Interv 2005; 64: 495-506.

18. Cowley CG, Orsmond GS, Feola P, et al. Long-term, randomized comparison of balloon angioplasty and surgery for native coarctation of the aorta in childhood. Circulation 2005; 111: 34533456.

19. Thanopoulos BD, Hadjinikolaou L, Konstadopoulou GN, et al. Stent treatment for coarctation of the aorta: intermediate term follow up and technical considerations. Heart 2000; 84: 65-70. 